Canadian Journal of Higher Education Revue canadienne d'enseignement supérieur

Volume 42, No. 3, 2012, pages 93-115

\title{
Exploring the Alignment Between Post-Secondary Education Programs and Earnings: An Examination of 2005 Ontario Graduates
}

Kristyn Frank \& David Walters

University of Guelph

\begin{abstract}
This study examines the influence that field of study and level of post-secondary education have on the earnings of recent graduates in Ontario. Graduates of trades, community college, and university programs are compared. Results suggest that graduates of applied and technical programs obtain higher earnings within two years of graduation than graduates of liberal arts programs. University graduates also fare better than college and trades graduates, whereas male graduates of trades programs are found to obtain higher earnings than college graduates. This study provides updated information for policy officials involved with allocating government funding to post-secondary education in Ontario.
\end{abstract}

\section{RÉSUMÉ}

La présente étude observe l'influence que peuvent avoir le domaine ainsi que le niveau d'études postsecondaires sur les revenus des nouveaux diplômés dans la province d'Ontario. Pour cela, nous avons mis en relation les diplômés du secteur technique, des collèges communautaires et des programmes universitaires. Les résultats suggèrent que les diplômés de programmes 
techniques et appliqués perçoivent un salaire plus élevé dans les années qui suivent l'obtention de leur diplôme que ceux des programmes des arts libéraux. De même, les diplômés universitaires sont plus rétribués que ceux des collèges communautaires et du secteur technique, alors qu'il s'avère que les hommes certifiés des programmes techniques sont plus rémunérés que les diplômés des collèges communautaires. Cette étude fournit des dernières informations en date aux fonctionnaires responsables des régulations et impliqués dans la redistribution du budget de l'état pour les études postsecondaires en Ontario.

The school-to-work transition of Ontario post-secondary graduates is a growing concern within Canada's "knowledge-based" economy, with increasing attention given to the skills possessed by recent graduates. There is some debate about whether the skills developed within post-secondary programs are a good fit with the requirements of the evolving knowledge economy. While some argue that graduates require technical and applied skills for this economy, others assert that generic skills offered by liberal arts programs, such as communication and critical thinking skills, are also in demand by employers. Although technical skills are required for the creation of new technology in this economy, an alternate perspective identifies a need for a variety of educated workers, including those who can evaluate, interpret, and communicate information in the knowledge economy.

The field of study and level of schooling of recent post-secondary graduates are thus salient aspects of their labour market outcomes. Previous research indicated that there has been consistent variability between graduates of different fields of study since the 1980 s, with graduates of applied programs generally obtaining higher earnings than liberal arts graduates soon after graduation. However, information about more recent cohorts is needed. The impact of new information technology and a greater concentration on producing workers for the knowledge economy has influenced changes in human resources needs and business activities. It is therefore important to study a recent cohort of graduates who made their school-to-work transitions during a time of rapid technological change.

Although many have examined labour market outcomes of previous cohorts at a national level, this study will focus specifically on Ontario graduates, providing a view of graduates' experiences at the provincial level. Because higher education policy is determined by provincial governments in Canada, an examination of students at the provincial level was determined to be most useful in providing policy-relevant information. Specifically we selected an Ontario sample for several reasons. First, Ontario has the highest postsecondary participation rate in Canada (Norrie \& Lin, 2009), thereby providing a sample size large enough to examine differences by level of schooling and field of study. Second, the Ontario government has been particularly concerned with the link between post-secondary education and labour market outcomes; past policy reforms in the province have increased funding to university programs that develop the technological skills "most in demand by industry" (Lin, Sweet, Anisef, \& Schuetze, 2000, p. 38). The education-labour market link also appears to be a top concern among Ontario students, as the majority of Canadian co-operative education graduates reside in Ontario (Walters \& Zarifa, 2008). 


\section{PREVIOUS LITERATURE}

The emergence of the knowledge economy has resulted in the growth of research examining the fit between post-secondary educational programs and the labour market outcomes of graduates. Characterized by the production of knowledge and technology, this economy has contributed to a common view that higher education and specialized training are imperative to the success of new labour market entrants (Finnie \& Usher, 2007; Lavoie \& Finnie, 1999; Stehr, 1994). There has been particular emphasis on the necessity of a highly skilled labour force to satisfy Canada's need for research and development in the environmental technology, information technology, and telecommunications fields, as well as in specific occupational fields such as engineering (Government of Canada, 2002; Statistics Canada, 1999). Although the knowledge economy has grown gradually since the early 1970 (Baldwin \& Beckstead, 2003), there has been more rapid change in recent years. Throughout the 1990 s and into the $21^{\text {st }}$ century, the increasing creation and development of information technology has significantly influenced how businesses operate and has subsequently affected the skills required to compete in this changing economy (Allen, 1999; Walters, 2004b).

Despite a general assumption that Canadian employers require more highly skilled employees (Baldwin \& Beckstead, 2003; Conference Board of Canada, 2007), questions have been raised regarding whether post-secondary education provides the resources to allow such skills to be developed (Canadian Council for Learning, 2008). Skill requirements for many occupations have increased over the past two decades, leading to the assumption that higher credentials and more specialized skill sets are necessary to succeed in the new economy (Gingras \& Roy, 2000). However, some have argued that employers' increased emphasis on higher levels of education was a case of "upskilling" in which the job responsibilities did not actually require such highly advanced knowledge or skills (Gingras \& Roy, 2000; Krahn \& Lowe, 1998). This argument has led some to question the value of a university education, especially when college programs offered more technical training in similar disciplines. A debate has thus emerged over the value of certain types of educational pathways in students' school-to-work transitions.

Nevertheless, the demand for highly skilled workers in the knowledge economy appears to have affected students' participation in post-secondary education in Ontario. Drewes (2010) found that the number of both university and college graduates in Ontario increased between 1986 and 2005. Ontario has also seen increased graduate student enrolments in recent years (Wiggers, Lennon, \& Frank, 2011). Walters (2004a) argued that this increase in schooling would continue as long as the cost of further education did not outweigh the prospect of future earnings. Thus, there is a direct relationship between post-secondary education and the labour market, a relationship that is primarily rooted in the human capital perspective. The positive relationship between level of education and earnings is well established in the human capital literature and has been largely influential in shaping education policy (Ashton \& Lowe, 1991; Walters, 2004a). The influence of this perspective has been apparent in Ontario's education policies since the 1960s, representing the assumption that increases in the demand for skills in the labour force required an increased investment in education and training (Taylor, 2005). 
The role of a liberal education in a technologically oriented society has consequently received increased attention from researchers. There was some skepticism regarding universities' increased response to labour market demands, as the reallocation of funds to more vocationally oriented programs may have come at the expense of liberal arts programs (Axelrod, 2002). Those who contended that there was a need for skills acquired through liberal arts programs argued that graduates of such programs can fulfil a need in the knowledge economy that graduates from technical programs cannot. Workers with broad problem-solving and critical thinking skills can use new technology in the workplace and have the ability to understand and analyze the abundant amount of information produced by the knowledge economy (Giles \& Drewes, 2001; Walters, 2004b). Some also noted that the future demand for particular skills cannot be predicted and that liberal arts graduates offered the type of skills that were more adaptable to a changing economy, providing them with a greater range of employment opportunities (Allen, 1999; Axelrod, Anisef, \& Lin, 2001; Brisbois, Orton \& Saunders, 2008; Giles \& Drewes, 2001). Students who acquired only specific technical skills may also risk future labour market success as their skills may become outdated because of continual changes in the economy (Axelrod, Anisef, \& Lin, 2001; Walters, 2004b). Conversely, proponents of vocational education asserted that graduates from applied and technical programs were more likely to obtain better job-skill matches (Human Resources Development Canada, 2001).

Due to the debates over the usefulness of liberal arts and applied programs, the field of study in which students choose to enrol is an important factor to consider when examining the labour market outcomes of recent graduates. Although increasing attention has been given to the impact of graduates' fields of study in their employment success (e.g., Axelrod, Anisef, \& Lin, 2001; Boudarbat, 2008; Finnie \& Frenette, 2003; Frenette, 2004; Hansen, 2006; Stark, 2007; Walters, 2003, 2004b), less research has been conducted using the most recent data available through the 2005 National Graduates Survey (NGS). One exception is Drewes's (2010) use of the 2005 NGS to examine whether graduates' field of study choices were in accordance with labour demand in Ontario's labour market. He found that there was a growing demand for graduates of the engineering, mathematics, and computer science fields.

Previous studies indicated that earlier cohorts of graduates in applied and technical fields generally fared better in the labour market than liberal arts graduates, particularly in terms of earnings and unemployment rates (Allen, 1999; Davies \& Guppy, 1997; Finnie, 2001, 2002; Lavoie \& Finnie, 1999; Lin, Sweet, \& Anisef, 2003; Silver, Lavalee, \& Pereboom, 1999; Walters, 2003, 2004b). This was particularly true for university graduates of applied fields. Specifically, graduates from business and commerce, computer sciences, engineering, health, and mathematics were consistently found to obtain higher earnings than graduates from other fields of study; graduates of the fine arts and the humanities typically obtained the lowest earnings (Allen, 1999; Finnie, 2001; Hansen, 2006; Lavoie \& Finnie, 1999; Lin, Sweet, \& Anisef, 2003; Silver, Lavalee, \& Pereboom, 1999; Stark, 2007; Walters, 2003, 2004b). Graduates of professional programs in fields such as education, engineering, health, and law were also more likely to obtain occupations directly related to their fields of study (Boothby, 2000; Finnie, 2001; Lavoie \& Finnie, 1999). With respect to Ontario graduates, a survey conducted by the Council of Ontario Universities (2009) found that, among 2006 graduates of undergraduate programs, those in profes- 
sional health fields (e.g., dentistry, optometry, pharmacy) had the highest average earnings two years after graduation, whereas applied and fine arts graduates had the lowest average earnings. However, although recent liberal arts graduates were typically found to earn less than their peers who graduated from applied programs such as engineering, some research suggested that the earnings of liberal arts graduates may catch up to and sometimes surpass their peers' earnings over time (e.g., Adamuti-Trache, Hawkey, Schuetze, \& Glickman, 2006; Allen, 1999; Giles \& Drewes, 2001; Heisz, 2001). With respect to level of education, previous research found that university graduates had a relative earnings advantage over community college and trade school graduates (Hansen, 2006; Walters 2004b).

Due to limited research on the school-to-work transitions of recent cohorts of graduates in Ontario, the effects that changes in the economy may have on new graduates from different fields of study are unclear. The proliferation of information technologies and information-sharing devices since the beginning of the $21^{\text {st }}$ century has affected how information is handled in the workplace in addition to changing how businesses approach advertising, communication, and sales (Walters, 2004b). Therefore, when identifying the impact of the changing economy on the labour market outcomes of post-secondary graduates, it is important that analyses involve graduates of the most critical cohort-those who made their school-to-work transitions during this period of rapid technological change.

\section{DATA AND METHODOLOGY}

This study is based on data from Statistics Canada's 2005 National Graduates Survey (NGS). ${ }^{1}$ The survey contained information on approximately 40,000 post-secondary graduates of various programs across all provinces and territories. A series of questions was asked via telephone that related to educational history and the employment profiles of the NGS respondents. The survey population was composed of all graduates of Canadian postsecondary educational institutions who had completed the requirements for degrees, diplomas, or certificates during the 2005 calendar year. Prior versions of the NGS have been used extensively in the research literature (Finnie, 2001; Krahn \& Bowlby, 1999; Taillon \& Paju, 1999; Walters, 2004b, 2006; Walters \& Zarifa, 2008; Zarifa \& Walters, 2008); however, very little research is available that examines data from the most recent NGS which contains data on post-secondary graduates of the 2005 cohort who were surveyed in 2007.2

Although the NGS is a useful data set with which to examine recent graduates' labour market outcomes, there are some limitations to the use of these data. Of note, particularly for this wave of the NGS, only short-term labour market outcomes can be determined. Due to the cancellation of the NGS, the 2005 cohort was not interviewed again in 2010. Therefore, the results here represent very early labour market outcomes for the cohort (i.e., two years after graduation). The short-term nature of these results should be kept in mind as previous literature indicated that longitudinal data provided better insight into graduates' choices throughout their adult lives (e.g., Andres \& Adamuti-Trache, 2008). Second, only graduates of post-secondary education programs can be examined. As a result, comparisons cannot be made with other individuals in the labour market. Therefore, the overall relevance of post-secondary education to individuals' labour market outcomes, and the extent of earnings advantage that post-secondary education may provide individuals, cannot be assessed. 
The key explanatory variables used for the analyses related to post-secondary programs of study: level of schooling and field of study. The level of schooling variable distinguished between graduates of trade certificate programs, community college diploma or certificate programs, ${ }^{3}$ university baccalaureate degree programs, and graduates of advanced university degree programs. Graduates of programs typically classified as "professional" (e.g., education, BEd; dentistry, DDS, DMD; law, LLB; medicine, MD; optometry, OD; veterinary medicine DVM) ${ }^{4}$ are grouped together with graduates of graduate (e.g., MA, PhD) programs. These programs were classified as "advanced" university degrees because they required at least some undergraduate (baccalaureate) schooling for admission to their programs; hence, these programs were generally not accessible to students directly out of high school or from community colleges. Moreover, graduates of these programs generally experienced more favourable labour market outcomes two years after graduation (Walters, 2004b). Graduates of community college graduate certificate programs were grouped with community college graduates. Graduates with university diplomas were excluded from the sample and were very small in number.

All respondents were asked to report their field of study. Their responses were originally converted into a field-of-study code applicable for all graduates, using a classification system developed by the National Center for Education Statistics in the United States and called the Classification of Instructional Programs (CIP). This process allowed Statistics Canada to aggregate the field of study codes into a smaller subset of categories to match the university student field of study categories and the community college and trade-vocational field of study categories. Because of issues relating to sample size, we grouped graduates from fields relating to education and recreational services with those from interdisciplinary or other studies. We also grouped liberal arts graduates together (e.g., fine arts, humanities, social sciences). Finally, graduates with credentials in fields relating to mathematics were grouped together with graduates in fields relating to engineering and applied sciences. The categories for aggregated field of study were as follow:

1. Liberal arts (e.g., fine arts, humanities, and social sciences)

2. Commerce, management, and business administration ${ }^{5}$

3. Physical, agricultural, and biological sciences

4. Engineering, computer sciences, and math

5. Health and related fields

6. Other (areas that could not be adequately captured in the above fields such as education, recreational and counseling services, interdisciplinary studies, unknown, or unclassified fields not specified and undeclared)

The statistical models also included the primary socio-demographic variables sex, marital status, age, mother's education, father's education, the presence of dependent children, and visible minority status. The parental education variables were used as proxies for socio-economic status. Also included were a series of variables that identified whether the respondents borrowed money from government or non-government sources to finance their schooling, ${ }^{6}$ along with variables that captured whether the respondents received bursaries, grants, or other scholarships ${ }^{7}$ over the course of their programs. These variables have been found to have significant relationships with earnings in research employing 2000 NGS data (Zarifa \& Walters, 2008). 
The response variable in the statistical analyses was earnings. The earnings variable was assessed via respondents' estimated gross annual earnings (in Canadian dollars) during the 2007 calendar year. The earnings variable was derived by Statistics Canada based on the respondent's reported salary, how it was paid (yearly, monthly, weekly, or hourly), and the number of hours usually worked. To be consistent with previous research employing NGS data, the analyses involving earnings applied to graduates with full-year employment who worked more than 30 hours a week. ${ }^{8}$ All graduates who obtained additional credentials or who were enrolled in an additional post-secondary program at the time of the survey were removed from all analyses because they were no longer considered to belong to the same educational group. Finally, a small number of observations were removed as a result of missing data, leaving 4,622 cases for the statistical analyses. All analyses employed the sample weights available in the NGS.

\section{DESCRIPTIVE RESULTS}

The descriptive statistics for the variables in this study are provided in Table 1 . With the exception of age, all of the explanatory variables used in the analysis were treated as categorical. We employed indicator (o/1 dummy) coding for categorical variables. The coding of these variables and corresponding reference categories are clearly identified in the tables. The categories and descriptive information relating to each variable in this study can be found in Table 1 .

The descriptive statistics in Table 1 revealed that the average age of respondents in the sample of post-secondary graduates (two years after graduation) was $31 .{ }^{9}$ Consistent with past research, more women than men graduated from post-secondary institutions in Ontario, where approximately $58 \%$ of post-secondary graduates from the overall sample were female. The majority of respondents were not married (58\%), and most (75\%) did not have dependent children. Post-secondary graduates reporting a visible minority status were outnumbered by their non-minority counterparts by a ratio of $3: 1$. In terms of parental education, slightly more than half of the respondents reported that their mother had at least some post-secondary schooling; the same applied to their father. Approximately $63 \%$ of respondents received a government student loan to subsidize the cost of schooling, while nearly $25 \%$ reported that they had received bursaries or grants to help pay for their post-secondary education. More than 35\% of respondents had received scholarships, while approximately $31 \%$ borrowed money from non-government sources.

With respect to field of study, most graduates came from fields classified as liberal arts (23\%) and business (22\%). Graduates of fields classified as engineering and as other (which includes interdisciplinary studies) each represented approximately $19 \%$ of the 2005 Ontario post-secondary graduates who were included in our analyses. Nearly $13 \%$ of post-secondary graduates in the sample had health-related credentials, while approximately $4 \%$ of the respondents had credentials classified as science oriented. The estimated median earnings of graduates who were employed full-time throughout the year was $\$ 48,160$.

The distribution of fields of study across levels of schooling can be found in Table 2 . Graduates of trades programs were most likely to come from the engineering/computer science fields (44\%), followed by other and health-related fields. Community college graduates were most likely to receive diplomas in fields relating to business (27\%), the liberal arts (23\%), and engineering/computer sciences (20\%). Graduates of university 
Table 1.

Descriptive Statistics for the Entire Sample for the Variables in the Analyses

\begin{tabular}{|c|c|}
\hline Variable & Percentage \\
\hline \multicolumn{2}{|l|}{ Sex } \\
\hline Female & 58 \\
\hline Male & 42 \\
\hline \multicolumn{2}{|l|}{ Marital Status } \\
\hline Married & 43 \\
\hline Not Married & 58 \\
\hline \multicolumn{2}{|l|}{ Dependent Children } \\
\hline Yes & 26 \\
\hline No & 75 \\
\hline \multicolumn{2}{|l|}{ Visible Minority Status } \\
\hline Visible Minority & 25 \\
\hline Non-Minority & 75 \\
\hline \multicolumn{2}{|l|}{ Mother Has Post-Secondary Education } \\
\hline No & 51 \\
\hline Yes & 49 \\
\hline \multicolumn{2}{|l|}{ Father Has Post-Secondary Education } \\
\hline No & 50 \\
\hline Yes & 50 \\
\hline \multicolumn{2}{|l|}{ Government Loans } \\
\hline No & 37 \\
\hline Yes & 63 \\
\hline \multicolumn{2}{|l|}{ Bursaries/Grants } \\
\hline No & 75 \\
\hline Yes & 25 \\
\hline \multicolumn{2}{|l|}{ Scholarships } \\
\hline No & 65 \\
\hline Yes & 35 \\
\hline \multicolumn{2}{|l|}{ Other Loans } \\
\hline No & 69 \\
\hline Yes & 31 \\
\hline \multicolumn{2}{|l|}{ Field of Study } \\
\hline Business & 22 \\
\hline Sciences & 4 \\
\hline Engineering/Computer Sciences & 19 \\
\hline Health & 13 \\
\hline Other & 19 \\
\hline Liberal Arts & 23 \\
\hline \multicolumn{2}{|l|}{ Level of Schooling } \\
\hline Trades & 17 \\
\hline College & 24 \\
\hline University (undergraduate) & 25 \\
\hline University (advanced) & 34 \\
\hline Age (mean) & 31 \\
\hline Yearly Earnings for Full Time (median, $n=4,622$ ) & $\$ 48,160$ \\
\hline
\end{tabular}


baccalaureate programs were most likely to receive degrees in the liberal arts (33\%), followed by business and engineering/computer sciences. Finally, university graduates with advanced degrees were most likely to have degrees in fields classified as other (28\%), followed by business and the liberal arts.

Table 2.

Distribution of Field of Study by Level of Schooling (in percent)

\begin{tabular}{lcccc}
\hline & Trades & Community College & University Undergrad & University Advanced \\
\hline Business & 14 & 27 & 22 & 25 \\
Sciences & - & 2 & 5 & 73 \\
Engineering/ & 44 & 20 & 16 & \\
Computer & & & & \\
Sciences & 18 & 14 & 11 & 28 \\
Health & 19 & 14 & 13 & 18 \\
Other & - & 23 & 33 & \\
Liberal Arts & - & & & \\
\hline
\end{tabular}

Note: Columns may not add to 100 due to rounding. Cells with a dash $(-)$ have $<20$ observations. $n=4,622$

\section{REGRESSION RESULTS}

The first set of results applied to all post-secondary graduates in Ontario who received their credentials in 2005. Thus, the results presented in Table 3 and Figure 1 included post-secondary graduates of all levels (trades, community college, university baccalaureate, and university graduates with advanced degrees). The second set of results, presented in Figure 2, applied only to community college and university baccalaureate graduates. The models were designed to tease out the interrelationship between field of study and level of schooling for those groups of graduates. The key explanatory variables in all models were field of study and level of schooling. All models controlled for the socio-demographic and funding-related variables discussed above.

Table 3 provides the regression results for earnings for graduates of trades, college, and university. Because the distribution of earnings was positively skewed with non-negative values, we used a regression model where a log transformation was employed for the response variable. The purpose of Model 1 was to assess the impact of field of study and level of schooling on earnings, controlling for the other variables in the model. Among the control variables, gender, marital status, age, visible minority status, father's education, and the variables representing whether the respondent borrowed from non-government sources and whether the respondent reported receiving scholarships were all statistically significant at $p<.001$. The parameter estimates for these variables were interpreted as follows: When controlling for the other variables in the model, males earned more than females, married graduates earned more than their single counterparts, and visible minorities earned less than non-minorities. Age was positively related to earnings. ${ }^{10}$

The effect of field of study was statistically significant $(p<$.001). The parameter estimates for this variable revealed that graduates of engineering/computer sciences reported the highest earnings, followed closely by those of health-related programs, and then followed by graduates with business-related credentials. The difference in reported earnings two years after graduation between these graduates and graduates with liberal arts 
Table 3.

Regression of Earnings on Level of Schooling, Field of Study, and Gender, Controlling for Socio-Demographic Characteristics

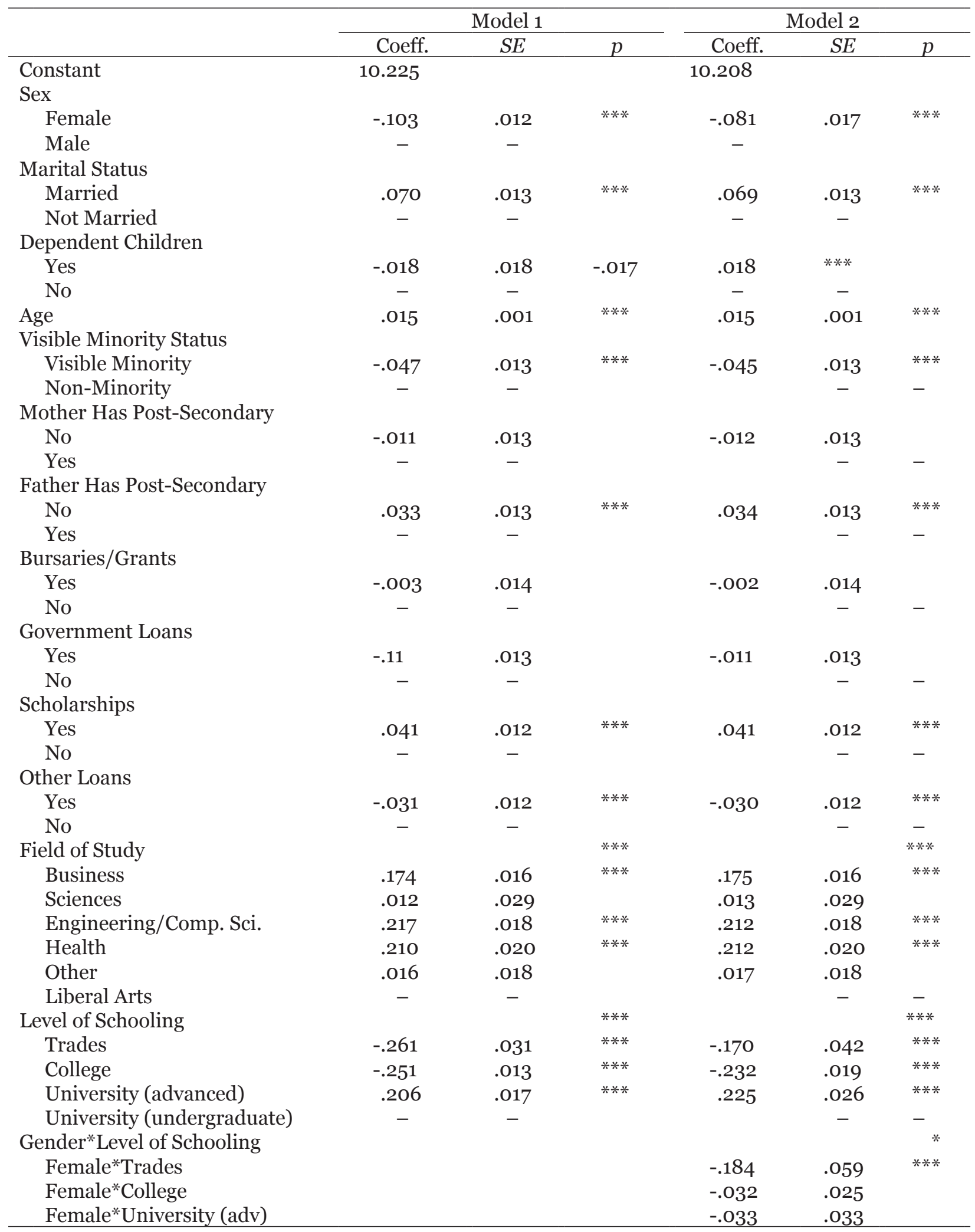


credentials (the reference category) was statistically significant $(p<.001)$. This finding provided evidence that the new economy continued to favour graduates with applied and technical skills over graduates with the more generalist skills provided in the liberal arts.

The effect of level of schooling was also statistically significant $(p<.001)$. When controlling for the effects of field of study and the other variables in the model, college graduates reported the lowest earnings, followed by graduates of trades programs (based on Model 2 estimates). Both groups of graduates earned significantly less than university graduates with undergraduate degrees $(p<.001)$. Graduates with advanced university degrees reported the highest earnings, significantly more two years after graduation than those with baccalaureate degrees $(p<.001)$.

The interaction between gender and level of schooling included in Model 2 was statistically significant $(p<.05) .{ }^{11}$ This finding implies that the effect of level of schooling on earnings depends on gender, and vice versa. The regression estimates for gender, level of schooling, and the interaction between gender and level of schooling in Model 2 of Table 3 were converted into meaningful quantities (dollars) by taking the inverse of the link function (exponentiation) and holding the other control variables constant at typical values. (We used the mean for age and proportions for the categorical variables.) The predicted values for earnings, along with corresponding $95 \%$ confidence intervals, were plotted in Figure 1 and were derived from the estimates in Model 2. The figure reveals the relationship between earnings and level of schooling separately for males and females. In general, the pattern of the earning estimates indicated that graduates with advanced credentials reported higher earnings. For example, graduates with advanced university degrees reported the highest earnings ( $\$ 58,943$ for males, $\$ 52,654$ for females), followed by university undergraduates ( $\$ 47,100$ for males, $\$ 43,446$ for females), and then followed by community college graduates $(\$ 37,327$ for males, $\$ 33,363$ for females). There was an interesting exception for the comparison of trades and community college graduates. Although females with community college diplomas have higher estimated earnings $(\$ 33,363)$ than their counterparts with trade certificates $(\$ 30,423)$, males who received trade certificates in 2005 had higher estimated yearly earnings in $2007(\$ 39,700)$ than their counterparts who graduated from community college programs in the same year $(\$ 37,327)$.

For all groups of post-secondary graduates, males earned significantly more than females; however, the gender gap in earnings varied slightly by level of schooling. When holding all other variables constant at typical values, the gender gap in yearly earnings was $\$ 6,289$ for university graduates with advanced degrees, $\$ 3,655$ for university graduates with baccalaureate degrees, $\$ 3,963$ for community college graduates, and $\$ 9,276$ for trades graduates.

\section{Examining Field of Study for Community College Graduates and University Baccalaureates}

The following regression model was based only on graduates of community college and university baccalaureate degree programs. The purpose of this analysis was to assess the impact of field of study on labour market outcomes for college and university graduates specifically, as they represented the two most common post-secondary pathways after high school. As well, because the focus of this section was on field of study, we 
Figure 1.

Predicted Earnings, Two Years After Graduation, for Male and Female Graduates of Trades, Community College, Baccalaureate, and Advanced-Degree University Programs

Earnings by Level of Schooling and Gender

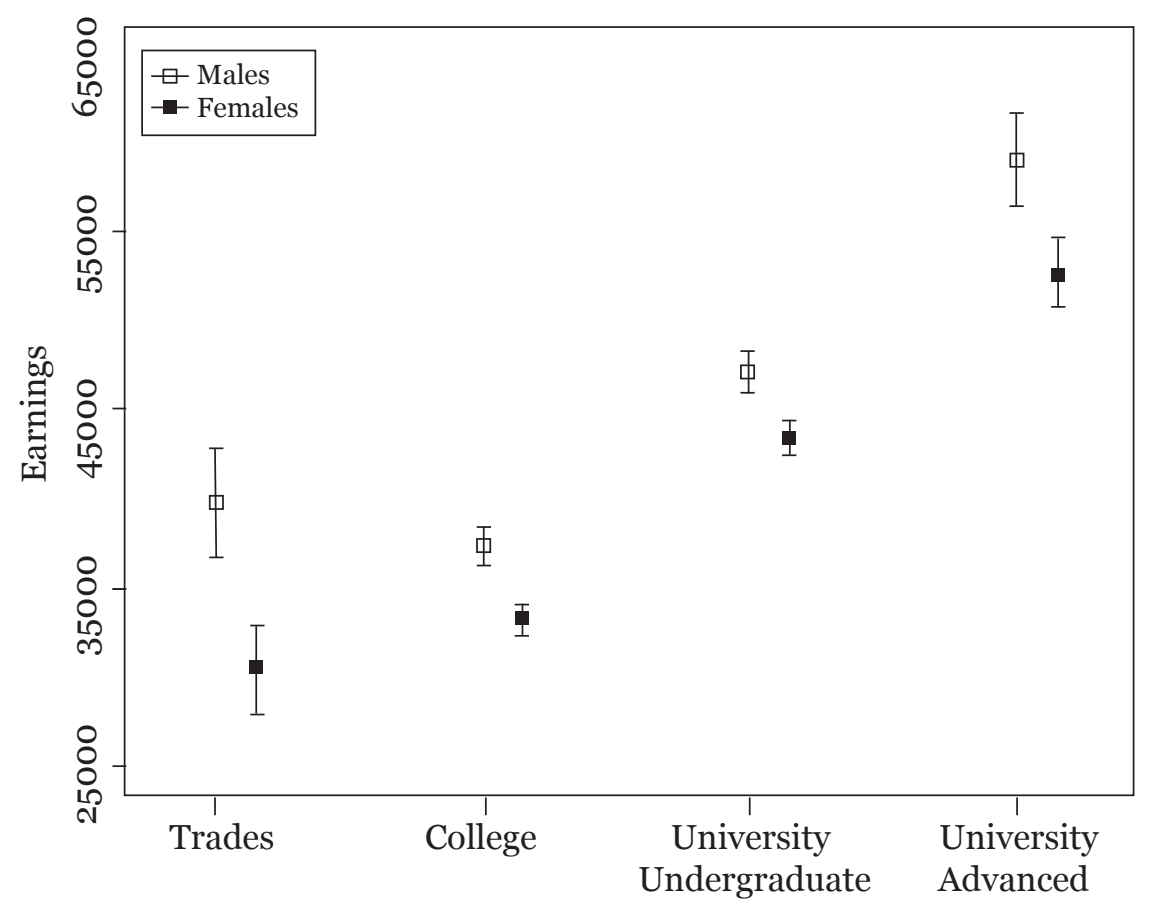

Note. The fitted earning values are calculated holding the control variables constant at typical values (means and proportions). Earnings are reported in 2007 Canadian dollars.

excluded trades graduates and university graduates with advanced degrees because the aggregated field of study comparisons became more challenging (e.g., Statistics Canada classifies graduates with law LLB degrees within the social sciences). Likewise, trades graduates have very few observations for some of the field of study categories.

Table 4 provides the parameter estimates for the regression of earnings on field of study for community college graduates and graduates of university baccalaureate programs $(n=$ 2,181 ). The direction of the effects for the socio-demographic control variables that were statistically significant was largely consistent with the previous regression models estimated for earnings. Males earned more than females $(p<.001)$, and married graduates earned more than unmarried graduates $(p<.01)$. Older respondents reported higher earnings than younger respondents $(p<.001)$, while visible minorities reported lower earnings than nonminorities. Graduates who reported that their father had a post-secondary education had slightly lower wages than respondents who reported that their father did not have a postsecondary education $(p<.05)$, controlling for the other variables in the model. ${ }^{12}$

Graduates who reported receiving a scholarship had higher earnings than those who did not report receiving a scholarship, which could in part reflect ability $(p<.001)$. Finally, post-secondary graduates who received financial assistance for their post-secondary schooling in the form of non-government loans reported slightly lower earnings $(p<.05)$ than graduates who did not borrow from non-government sources for their education. 
Table 4.

Regression of Earnings on Level of Schooling and Field of Study for Community College and University Baccalaureates, Controlling for Socio-Demographic Characteristics

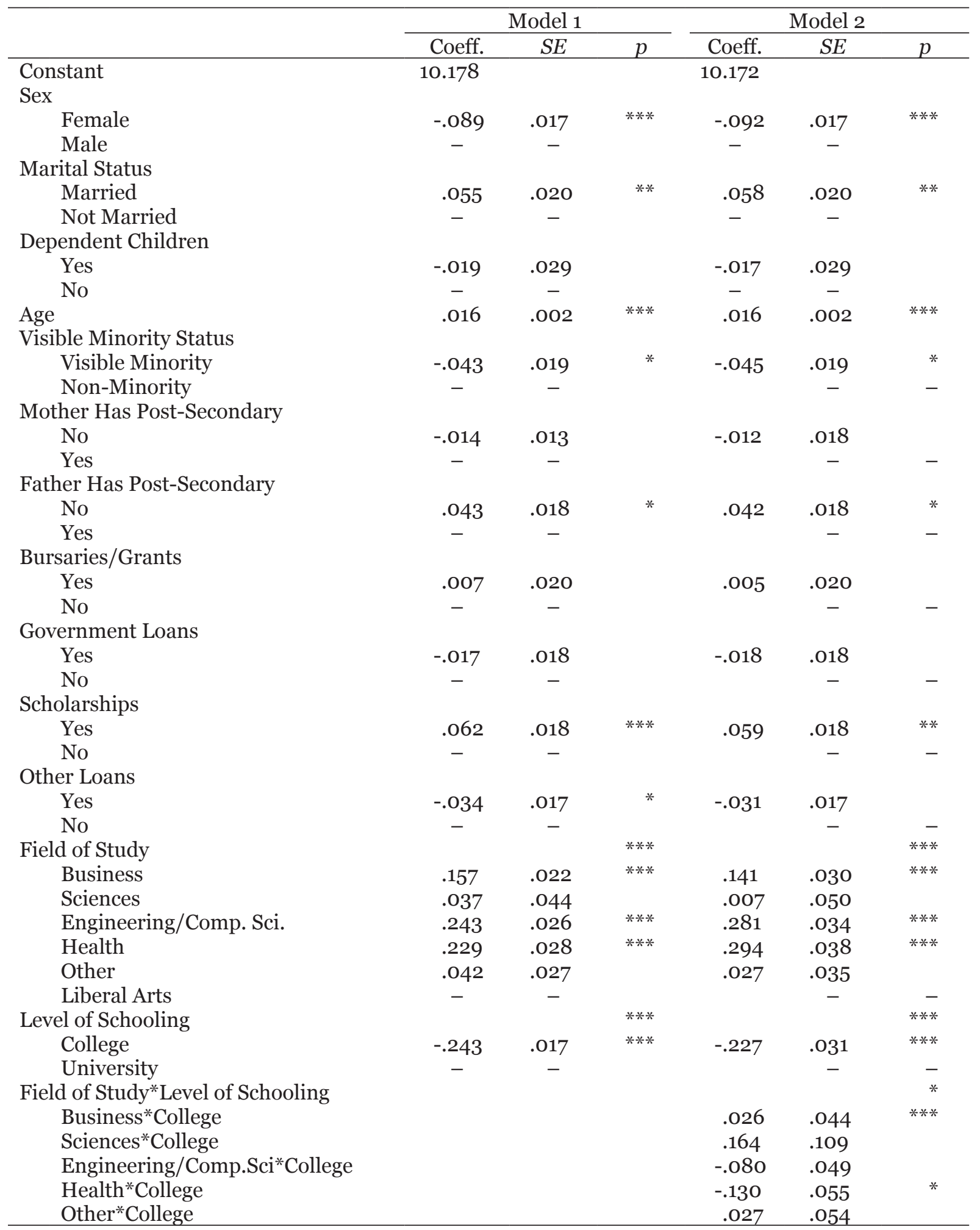

${ }^{*} p<.05 ;{ }^{* *} p<.01 ;{ }^{* * *} p<.001$.

$n=2,181$ 
Similar to the previous analyses, the effect of field of study was statistically significant $(p<.001)$. The parameter estimates for field of study revealed that among 2005 community college and university graduates in Ontario, those of the liberal arts programs (reference category) reported the lowest earnings two years after graduation. In comparison, graduates with credentials in engineering/computer sciences, health, and business, reported earnings that are significantly higher than graduates with liberal arts credentials ( $p$ <.001). Consistent with past research employing national data (e.g., Walters, 2004b), university graduates with baccalaureate degrees earned more two years after graduation than community college graduates.

The effect of the interaction between field of study and level of schooling (i.e., college, university) in Model 2 (Table 4) was statistically significant $(p<.01)$, revealing that the impact of field of study on earnings was different for community college graduates than it was for baccalaureate university graduates..$^{13}$ To better assess the interrelationship between field of study and earnings for college and university graduates, the log-earnings estimates involving level of schooling, field of study, and the interaction between field of study and level of schooling were converted to earnings and plotted in Figure 2, holding the values of other variables constant.

Figure 2.

Predicted Earnings, Two Years After Graduation, for Community College and Baccalaureate-Level University Programs of Various Fields of Study

Earnings by Field of Study for College and University Graduates

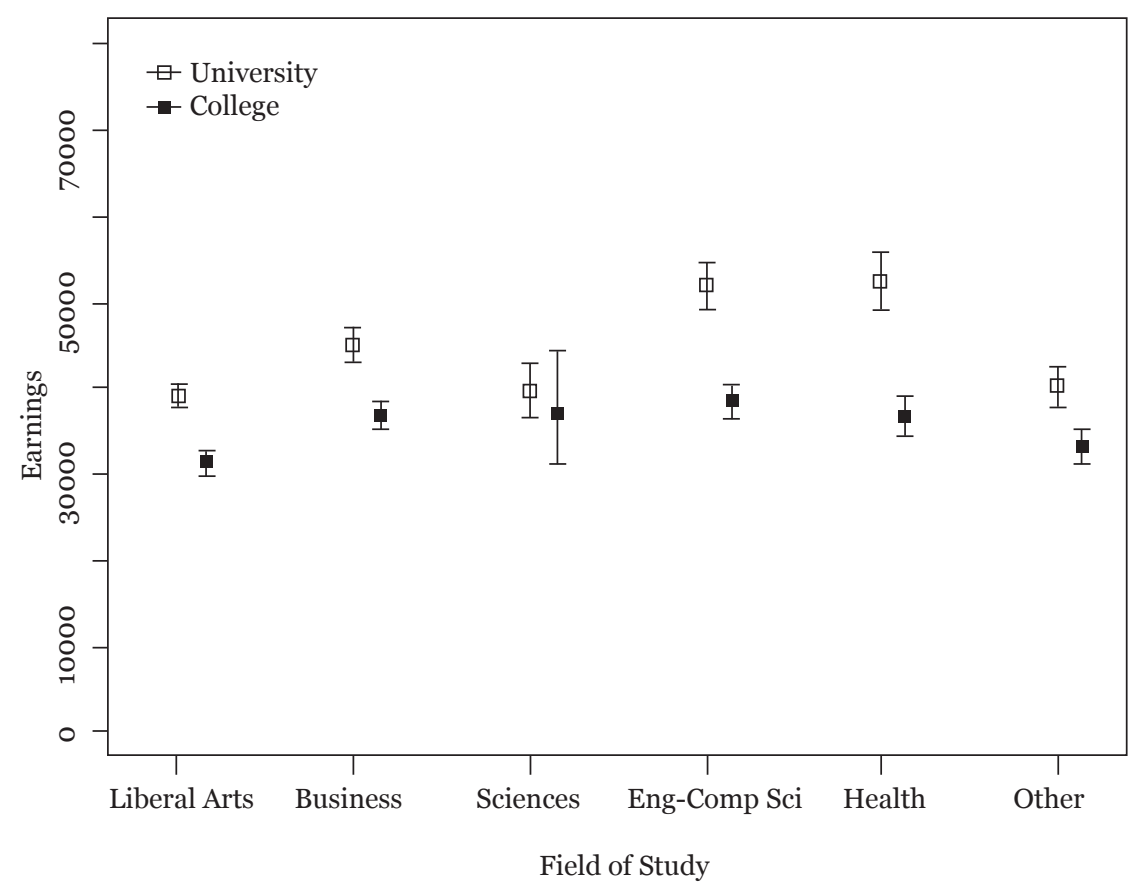

Note. The fitted earning values are calculated holding the control variables constant at typical values. Earnings are reported in 2007 Canadian dollars. 
Figure 2 reveals that field of study appeared to be a more important marker of stratification among university graduates than community college graduates. For example, among university graduates, the average yearly earnings ranged from \$38,958 (liberal arts) to $\$ 52,141$ (health). In between were graduates of sciences $(\$ 39,191)$, other fields $(\$ 40,031)$, business $(\$ 44,886)$, and engineering/computer sciences $(\$ 51,671)$. In comparison, the range in earnings among community college graduates was much smaller, from $\$ 31,095$ for graduates with diplomas in the liberal arts to $\$ 38,038$ for graduates with diplomas in engineering/computer sciences. The results in Figure 2 clearly revealed that, regardless of level of schooling (college or university), graduates of technical and applied fields reported stronger earnings than graduates of liberal arts fields. Nevertheless, the predicted earnings of university graduates with degrees in the liberal arts were significantly higher than the predicted earnings of community college programs for all fields except engineering.

\section{DISCUSSION}

Findings from this study indicate that field of study remains a salient aspect in determining post-secondary graduates' earnings within two years of graduation. This is particularly true in the examination of university graduates with a baccalaureate degree. The effect of level of schooling is generally consistent with human capital theory, indicating that graduates with the highest levels of education (advanced university) obtain the highest earnings. Because higher levels of education typically involve lengthier and more costly programs than lower levels, these results indicate that investments in higher levels of schooling generally result in greater labour market rewards among Ontario graduates. However, this result is somewhat complicated by the finding that male graduates of trades programs experience an earnings advantage over college graduates.

Gender differences are also found, as males at all levels of post-secondary education obtain higher earnings than their female counterparts. However, the results generally indicate that the higher the level of education, the greater is the labour market payoff for both genders. Notably, the earnings gap between genders is widest at the trades level. This finding may be due to occupational segregation by gender, as women in the trades pursue more service-oriented occupations, whereas men predominantly pursue occupations with higher remuneration in the construction and manufacturing trades (Statistics Canada, 2009).

The examination of earnings by field of study provides results that are similar to the labour market outcomes found in previous cohorts of graduates (e.g. Finnie, 2001; Stark, 2007; Walters, 2003, 2004b). Data from the 2005 cohort indicate that Ontario graduates of applied and technical fields continue to fare better than liberal arts graduates shortly after graduation. Generally, graduates of engineering/computer science programs obtain the highest earnings within two years of graduation, followed by graduates of health and business/commerce programs. Thus, the knowledge economy does appear to favour graduates with applied and technical skills over those graduates with generic skills, though graduates of baccalaureate liberal arts programs continue to obtain higher earnings than graduates of college programs in the liberal arts, business, and health. Although these findings are in accordance with previous research, they should only be applied to the Ontario population of recent graduates. 
Liberal arts degrees may not translate into the highest earnings shortly after graduation, but it does appear that these graduates are more highly remunerated than graduates of non-university programs. These results suggest that the skills Ontario liberal arts graduates develop in university are marketable in the labour market, even shortly after graduation. This finding also supports Heisz's (2003) conclusion that both the skills developed by liberal arts graduates and those developed by graduates of applied programs are valued by employers in the knowledge economy.

Results examining graduates' success by level of schooling offer some notable findings. While these results generally support the human capital assumption that higher levels of education result in greater labour market rewards, findings from this study also reveal an important exception to this linear assumption. Although recent Ontario graduates with advanced university degrees obtain the highest earnings, followed by university graduates with baccalaureate degrees, there is some discrepancy at the college and trades levels of education. The data indicate that male graduates of trades programs obtain higher earnings than college graduates, contrasting with previous findings (Allen, 1999; Walters, 2004b). This discrepancy may be due to the increased need for workers in the skilled trades; graduates of trades programs may in fact be benefiting from an undersupply of skilled trades workers in the labour market (Pyper, 2008). This finding may be unique to the Ontario labour market where there is a very strong manufacturing base relative to other provinces.

It does not appear that college graduates have closed the gap with university graduates in terms of their labour market returns to education. There is also evidence that male graduates of trades programs experience higher earnings than college graduates in Ontario. This result is of particular interest in the changing economy and should be examined further in future research, particularly given recent concern over the supply of skilled workers in the trades and the creation of Ontario's "Second Career" program which seeks to train workers for occupations that are currently in demand (Ministry of Training, Colleges and Universities, 2010). Unfortunately because of the cancellation of the NGS, data regarding the labour market experiences of this cohort during the recent economic downturn will not be available. However, further research exploring how recent graduates fared during this recessionary period would be of interest, particularly in addressing questions about which skills and educational training are more marketable and resilient in a tight labour market and economic recession.

Although the results of this study are based on the early labour market outcomes of recent graduates in Ontario, they do provide some insight that may be useful to policy-makers, administrators at post-secondary institutions, and students themselves. The main policy implications of examining the alignment between post-secondary education programs and the earnings of a recent cohort of graduates relate to funding and budgetary decisions for educational programs in Ontario. Because the funding of post-secondary education constitutes a large amount of the total spending of provincial governments, an increased focus on the "exchange value" of post-secondary education has influenced governments to base their funding on graduates' labour market outcomes (Axelrod, Anisef, \& Lin, 2001, p. 49). The consequences of basing funding decisions on these outcomes by field of study are potentially short-sighted, because the skills currently required by employers may not be in demand in the future (Axelrod, Anisef, \& Lin, 2001; Walters, 2004b). In addition, research suggests that changes in technology have increased the need for graduates of both applied and liberal arts programs (e.g., Heisz, 2003). 
Admissions strategies and tuition fees are also affected by the labour market outcomes of graduates from different fields of study. Some encourage increasing the number of spaces available in programs deemed in more demand by employers (e.g., Martin Property Institute, 2007). Tied to this issue, tuition levels for different fields of study may be further affected by the labour market outcomes of recent graduates. Inequities resulting from differences in tuition levels by fields of study may become larger as applied fields already have substantially higher tuition levels than liberal fields such as the humanities and social sciences (Statistics Canada, 2011). Because students often choose their field of study based on anticipated earnings after graduation, programs that yield high returns in the labour market are likely to be in higher demand (Boudarbat, 2004). However, if the costs of these programs far outweigh their future returns, significant tuition increases to these programs may be problematic, particularly if graduates of non-applied programs close the earnings gap over the long term as some research has found (e.g., Heisz, 2001).

Students themselves are increasingly concerned with the job skills that their educational programs offer. Student debt levels from educational costs have increased for both college and university graduates (Millennium Foundation, 2007). Therefore, the fields of study choices made by students are more likely to be based on potential earnings than previous generations. The findings presented here provide Ontario students with some notion of what to expect shortly after graduation, during their school-to-work transition. Although the short-term nature of these findings should be kept in mind, the labour market outcomes of graduates in the two years immediately following graduation have been found to have a strong influence on their eventual outcomes later in their careers (Anisef, Turrittin, \& Lin, 1999).*

\section{NOTES}

1. The research and analysis presented are based on data from Statistics Canada and were conducted at the South-Western Ontario Research Data Centre. The views expressed are those of the researchers and do not represent the views of Statistics Canada.

2. We would like to note that Statistics Canada's webpage states that the NGS has "some under-coverage for graduates of colleges in some provinces. Data required to build the frame could not be obtained from a few institutions and therefore, graduates from those institutions were not included on the frame. Consequently, they could not be selected nor represented in any tabulation. It is estimated that approximately 10,000 college graduates in Ontario and 5,000 college graduates in Alberta are missing from the survey population. No adjustment was made at the weighting stage to compensate for this under-coverage" (see http://www.statcan.gc.ca/cgi-bin/imdb/p2SV.pl?Funct ion $=$ getSurvey $\&$ SDDS $=5012 \& l a n g=e n \& \mathrm{db}=\mathrm{imdb} \& \mathrm{adm}=8 \& \mathrm{dis}=2$ ).

3. In 2005 community college programs were structured to provide graduates with either a certificate or a diploma rather than a baccalaureate degree.

4. Technically, these are undergraduate programs; however, they are typically classified as "professional" because they are required for access into highly regulated professions. Admission to professional programs is also much more competitive than standard undergraduate programs.

5. To be consistent with previous research (Finnie, 2001), graduates of economics programs were placed with graduates of commerce, management, and business administration. 
6. These variables may also represent proxies for socio-economic status, because students from lower socio-economic families were more likely to borrow money to fund their post-secondary education.

7. The scholarships variable was likely related to post-secondary programs; for example, graduates of graduate university programs were more likely to receive scholarships than graduates of all other programs. The variable was also likely to indirectly tap into ability (or aptitude), because scholarships were also closely tied to students' grades and academic standing.

8. The inclusion of only those who worked full-time and full-year resulted in the exclusion of those who worked in part-time and casual employment. Therefore, many recent college graduates may have been excluded, particularly in the health field (Ministry of Training, Colleges \& Universities, 2009).

9. The mean age of the total sample was higher than that found in other studies of graduates due to the inclusion of graduates of trades programs and advanced university degrees in our sample. Because the mean age for both of these groups was 33 and because trades and advanced degree graduates constituted just over half of the total sample, the mean age was slightly higher than in other studies that concentrate only on baccalaureate and community college graduates. The age may also have been skewed upward due to the inclusion of only those who were employed full-time and full-year, because older graduates were more likely to have worked before and/or during their educational programs. These individuals would likely have a greater connection to the labour market and more work experience, which could be associated with a greater likelihood of full-time and full-year employment.

10. We originally included an orthogonal polynomial contrast for age to assess whether the relationship between age and earnings was curvilinear-a common finding in labour market research. The polynomial estimates were not statistically significant in any of the models we estimated, probably because very few recent post-secondary graduates were over the age of 45 . Thus, they were removed from the analyses.

11. This interaction was the only one we tested that was statistically significant. We did not test for an interaction between level of schooling and field of study because the field of study groups were not adequately represented across all levels of schooling. (For example, there were very few graduates with trade certificates in the sciences or the liberal arts.) The interaction between gender and field of study was not statistically significant, and it was removed from the analyses.

12. Interestingly, when the effect of mother's education was excluded from the model, the estimate for father's education was not statistically significant, which was not inconsistent with other research employing NGS data that controls for similar variables. The unexpected negative estimate for father's education could be related to the association between these explanatory variables in this sample of graduates; it was similar to a suppression effect in economics. The estimate may also be related to the coding of the father's education variable. For example, the Yes category included graduates who reported that their father had any post-secondary education, including trades, college, or university, not just fathers with a university degree.

13. The substantive interpretations relating to the control variables in the model did not change when the interaction term was included in the model. Thus, they were not interpreted. 


\section{REFERENCES}

Adamuti-Trache, M., Hawkey, C., Shuetze, H. G., \& Glickman, V. (2006). The labour market value of liberal arts and applied education programs: Evidence from British Columbia. Canadian Journal of Higher Education, 36(2), 49-74.

Allen, R. C. (1999). Education and technological revolutions: The role of the social sciences and the humanities in the knowledge based economy. Retrieved from http:// www.fass.sfu.ca/documents/doc/35

Andres, L., \& Adamuti-Trache, M. (2008). Life course transitions, social class, and gender: A fifteen year perspective of the lived lives of Canadian young adults Journal of Youth Studies, 11(2), 115-145.

Anisef, P. Turrittin, A. H., \& Lin, Z. (1999). Social mobility 20 years after high school: Social and geographical dimensions. In W. Heinz (Ed.), From education to work: Cross national perspectives (pp. 25-45). New York, NY: Cambridge University Press.

Ashton, D., \& Lowe, G. (1991). Making their way: Education, training and the labor market in Canada and Britain. Toronto, ON: University of Toronto Press.

Axelrod, P. (2002). Values in conflict. Kingston, ON: McGill-Queen's University Press.

Axelrod, P., Anisef, P., \& Lin, Z. (2001). Against all odds? The enduring value of liberal education in universities, professions, and the labour market. Canadian Journal of Higher Education, 31(2), 47-78.

Baldwin, J. R., \& Beckstead, D. (2003). Knowledge workers in Canada's economy, 1971-2001. Catalogue No. 11-624-MIE No. 004. Ottawa, ON: Statistics Canada.

Boothby, D. (2000). The trade-vocational educational pathway in Canada: 1990 trade-vocational graduates in the 1992 National Graduates and 1995 Follow-up Surveys. Applied Research Branch Strategic Policy Paper No. R-oo-1-6E. Hull, QC: Human Resources Development Canada.

Boudarbat, B. (2008). Field of study choice by community college students in Canada. Economics of Education Review, 27(1), 79-92.

Boudarbat, B. (2004). Earnings and community college field of study choice in Canada. IZA. Discussion Paper No. 1156.http://ftp.iza.org/dp1156.pdf.

Brisbois, R., Orton, L., \& Saunders, R. (2008). Connecting supply and demand in Canada's youth labour market. Canadian Policy Research Networks, Pathways to the Labour Market Series, No. 8. Retrieved from http://www.cprn.org/documents/49679_EN.pdf

Canadian Council for Learning. (2008). The benefits of experientiallearning. Retrieved from http://www.ccl-cca.ca/pdfs/LessonsInLearning/Feb-21-o8-Benefit-of-exper.pdf

Conference Board of Canada. (2007). Ontario's looming labour shortage challenges: Projections of labour shortages in Ontario, and possible strategies to engage unused and underutilized human resources. Ottawa, ON: Author.

Council of Ontario Universities. (2009). Highlights from the Survey of 2006 Graduates of Ontario University Undergraduate Programs. Retrieved from http://www. cou.on.ca/Issues-Resources/Student-Resources/Surveys.aspx 
Davies, S., \& Guppy, N. (1997). Fields of study, college selectivity, and student inequalities in higher education. Social Forces, 75(4), 1417-1438.

Drewes, T. (2010). Postsecondary education and the labour market in Ontario. Toronto, ON: Higher Education Quality Council of Ontario.

Finnie, R. (2001). Fields of plenty, fields of lean: The early labour market outcomes of Canadian university graduates by discipline. Canadian Journal of Higher Education, 31(1), 141-176.

Finnie, R. (2002). Early labour market outcomes of recent Canadian university graduates by discipline: A longitudinal, cross-cohort analysis. Catalogue No. 164. Ottawa, ON: Statistics Canada.

Finnie, R., \& Frenette, M. (2003). Earnings differences by major field of study: Evidence from three cohorts of recent Canadian graduates. Economics of Education Review, 22(2), 179-198.

Finnie, R., \& Usher, A. (2007). Room at the top: Strategies for increasing the number of graduate students in Canada. C. D. Howe Institute. Retrieved from http://www. cdhowe.org/pdf/commentary_245.pdf

Frenette, M. (2004). The overqualified Canadian graduate: The role of academic program in the incidence, persistence, and economic returns to overqualification. Economics of Education Review, 23, 29-45.

Giles, P., \& Drewes, T. (2001). Liberal arts degrees and the labour market. Perspectives. Catalogue No. 75-001-XPE. Ottawa, ON: Statistics Canada.

Gingras, Y., \& Roy, R. (2000). Is there a skill gap in Canada? Canadian Public Policy, 26(1), S159-S174.

Government of Canada. (2002). Achieving excellence: Investing in people, knowledge, and opportunity. Retrieved from http://publications.gc.ca/collections/Collection/C2596-2001E.pdf

Hansen, J. (2006). Returnstouniversity level education: Variations within disciplines, occupations and employment sectors. Catalogue No. SP-662-09-06E. Gatineau, QC: Human Resources and Social Development Canada.

Heisz, A. (2001). Income prospects of British Columbia university graduates. Catalogue No. 11Foo19MPE, Paper No. 170. Ottawa, ON: Statistics Canada.

Heisz, A. (2003). Cohort effects in annual earnings by field of study among British Columbia university graduates. Catalogue No. 11Fo019, No. 200. Ottawa, ON: Statistics Canada.

Human Resources Development Canada. (2001). The school-to-work transition of post-secondary graduates in Canada: Research findings based on the National Graduates Surveys. Applied Research Bulletin Special Edition. Retrieved from http:// publications.gc.ca/collections/Collection/MP32-27-2001-3E.pdf

Krahn, H., \& Bowlby, J. W. (1999). Education-job skills match: An analysis of the 1990 and 1995 National Graduate Surveys. Applied Research Branch for Strategic Policy. Ottawa, ON: Human Resources Development Canada. 
Krahn, H., \& Lowe, G. S. (1998). Measuring the fit or mismatch between university education and employment outcomes. School-Work Transitions Project Report 98-1. Edmonton, AB: Population Research Laboratory, University of Alberta.

Lavoie, M., \& Finnie, R. (1999). Is it worth doing a science or technology degree in Canada? Empirical evidence and policy implications. Canadian Public Policy, 25(1), 101-121.

Lin, Z., Sweet, R., \& Anisef, P. (2003). Consequences and policy implications for university students who have chosen liberal or vocational education in Canada: Labour market outcomes and employability skills. Higher Education Policy, 16, 55-85.

Lin, Z., Sweet, R., Anisef, P., \& Schuetze, H. (2000). Consequences and policy implications for university students who have chosen liberal or vocational education: Labour market outcomes and employability skills. Catalogue No. R-o0-2-3E. Ottawa, ON: Human Resources Development Canada.

Martin Prosperity Institute. (2007). Path to the 2020 Prosperity agenda. Retrieved from http://www.competeprosper.ca/download.php?file=ICP_AR6_final.pdf

Millennium Foundation. (2007). The price of knowledge: Access and student finance in Canada (3rd ed.). Montreal, QC: Canadian Millennium Scholarship Foundation.

Ministry of Training, Colleges and Universities. (2010). What is second career? Government of Ontario. Retrieved from http://www.tcu.gov.on.ca/eng/secondcareer/ whatitis.html

Norrie, K., \& Lin, S. (2009). Postsecondary educational attainment and participation in Ontario. Toronto: ON: Higher Education Quality Council of Ontario.

Pyper, W. (2008). Skilled trades employment. Perspectives on Labour and Income. Catalogue No. 75-001-X. Ottawa, ON: Statistics Canada.

Silver, I., Lavallee, L., \& Pereboom, B. (1999). Labour market transitions of graduates. Catalogue No. R-001-9E. Ottawa, ON: Human Resources Development Canada.

Stark, A. (2007). Which fields pay, which fields don't? An examination of the returns to university education in Canada by detailed field of study. Retrieved from http://www. oecd.org/dataoecd/4/5/37578152.pdf

Statistics Canada. (1999). Innovation Analysis Bulletin, 1(1). Retrieved from http:// www.statcan.gc.ca/pub/88-003-x/88-003-x1999001-eng.pdf

Statistics Canada. (2009, June 25). Registered apprenticeship training programs. The Daily. http://www.statcan.gc.ca/daily-quotidien/090625/dq090625-eng.pdf

Statistics Canada. (2011, September 16). University tuition fees, 2011/2012. The Daily. http//:www.statcan.gc.ca/daily-quotidien/110916/dq110916-eng.htm

Stehr, N. (1994). Knowledge societies. Thousand Oaks, CA: Sage.

Taillon, J., \& Paju, M. (1999). The Class of 1995: Report of the 1997 National Survey of 1995 Graduates. Catalogue No. SP-121-04-99. Ottawa, ON: Human Resources Development Canada and Statistics Canada

Taylor, A. (2005). "Re-culturing" students and selling futures: School-to-work policy in Ontario. Journal of Education and Work, 18(3), 321-340. 
Walters, D. (2003). Recycling: The economic implications of obtaining additional postsecondary credentials at lower or equivalent levels. Canadian Review of Sociology and Anthropology, 40(4), 463-480.

Walters, D. (2004a). Evaluating the extent to which postsecondary education provides graduates with skills that they later use on the job: Comparing credentialism with human capital theory of education. Canadian Journal of Higher Education, 34(3), 97-124.

Walters, D. (2004b). A comparison of the labour market outcomes of postsecondary graduates of various levels and fields over a four-cohort period. Canadian Journal of Sociology, 29(1), 1-27.

Walters, D. (2006). An examination of the school-to-work transitions of male and female college and university graduates of applied and liberal arts programs in Canada. Higher Education Policy, 19, 225-250.

Walters, D., \& Zarifa, D. (2008). Do cooperative programs improve the school-towork transitions of postsecondary graduates in Canada? Journal of Vocational and Educational Training, 60(4), 377-400.

Wiggers, R., Lennon, M. C., and Frank, K. (2011). Expanding opportunities for graduate studies: The recent experience of Ontario. Toronto, ON: Higher Education Quality Council of Ontario.

Zarifa, D., \& Walters, D. (2008). Revisiting Canada's brain drain: Evidence from the 2000 cohort of Canadian university graduates. Canadian Public Policy, 34(3), 305-319.

\section{CONTACT INFORMATION}

Kristyn Frank

Department of Sociology and Anthropology

University of Guelph

Mailing address: R.H. Coats Building, 24th Floor

100 Tunney's Pasture Driveway

Ottawa ON K1A oT6 Canada

kfrank78@hotmail.com

David Walters

Department of Sociology and Anthropology

University of Guelph

Mackinnon Building, 6th Floor

50 Stone Road East

Guelph ON N1G 2W1 Canada

dwalters@uoguelph.ca

Kristyn Frank was a SSHRC postdoctoral fellow in the Department of Sociology and Anthropology at the University of Guelph when this research was conducted. She is now a researcher with the Social Analysis division at Statistics Canada. Her primary areas of research include students' field of study choices and their labour market outcomes as well as the social and economic integration of immigrants in Canada. 
David Walters is Associate Professor in the Department of Sociology and Anthropology at the University of Guelph. His substantive research interests and publications include school-to-work transitions of post-secondary graduates of various levels and fields of study. His recent research also examines inequality among various immigrant and ethnic groups. 